\title{
Deglacial patterns and ice-sheet dynamics in the fjords of southern Nordland, Norway
}

\author{
Fredrik Høgaas' ${ }^{1}$ Lars Olsen', Lina Gislefoss' ${ }^{1}$, Oddvar Longva' , Anders Romundset ${ }^{1}$ \\ \& Harald Sveian'
}

${ }^{1}$ Geological Survey of Norway, P.O. Box 6315 Torgarden, NO-7491 Trondheim, Norway.

E-mail corresponding author (Fredrik Høgaas): fredrik.hogaas@ngu.no

This paper presents results from glacial geomorphology mapping in and adjacent to Velfjorden and Ursfjorden in the southern Nordland region of Norway. Submarine and terrestrial landforms were studied and mapped using high-resolution multibeam bathymetric and airborne LiDAR data, in addition to reconnaissance in the field. The work unites ice-marginal deposits related to the established Tautra and Tjøtta glacial events which took place during the Younger Dryas (YD) chronozone. In Ursfjorden, an outlet glacier deposited a c. 100 m-high terminal moraine, whereas moraine ridges and a large sedimentary wedge were deposited in the inner part of Velfjorden. Highly elongated subglacial bedforms located inside the ice-marginal landforms reveal that the fjords were occupied by fast-flowing ice streams during YD. Eighteen new radiocarbon dates from the region, along with twelve recalibrated dates from previous studies, provide time-constraints for ice-sheet configuration and dynamics during deglaciation. Radiocarbon dates suggest that the outer coastal islands became ice-free prior to 14 cal ka BP. Glacially overridden shell-rich units dated to the Allerød Interstadial indicate that the YD ice sheet readvanced at least $5 \mathrm{~km}$ before depositing the terminal moraine in Ursfjorden. The ages of shells found near the distinct, regionally correlative, YD raised shoreline indicate that the glacial readvance culminated around early to mid-YD.

Keywords: Deglaciation, The Scandinavian Ice Sheet, Younger Dryas, Allerød

Received 3. May 2018 / Accepted 18. December 2018 / Published online 15. March 2019

\section{Introduction}

Ice-marginal features deposited during the Younger Dryas (YD) chronozone - 12.7-11.5 cal ka BP (Lohne et al., 2013) - are traceable around a large part of the former Scandinavian Ice Sheet (Andersen et al., 1995; Mangerud et al., 2011). In southern Nordland in Norway, the maximum ice sheet extent during YD was attained during the Tjøtta (or B) glacial event (Fig. 1; Andersen et al., 1982). Marginal moraines related to the event have been traced onshore (Andersen et al., 1981; Hansen et al., 2018), whilst large submarine icemarginal deposits have been identified and mapped in the outer parts of the fjords (Andersen et al., 1982; Lyså et al., 2004). Bargel (2003) mapped end moraines and ice-marginal features in the outer Tosenfjord region
(Fig. 2) just south of our study area, adding observations and radiocarbon chronology to previous work done by Svensson (1959). The deposits mapped by Bargel (2003) are morpho-stratigraphically correlated with moraines deposited during the Tautra glacial event in the Trondheimsfjorden-Fosen peninsula region (Fig. 1), where a number of radiocarbon dates suggest that the moraines were deposited early in the YD (Reite, 1994; Olsen et al., 2015). Few absolute dates related to the deglacial phase exist for the southern Nordland region, however, and the overall deglaciation chronology in this sector of the Scandinavian Ice Sheet is poorly constrained (Hughes et al., 2016).

This study aims to connect the ice-marginal zones deposited during the Tjøtta and Tautra YD glacial events and further to characterise the general distribution of

Høgaas, F., Olsen, L., Gislefoss, L., Longva, O., Romundset, A. \& Sveian, H. 2018: Deglacial patterns and ice-sheet dynamics in the fjords of southern Nordland, Norway. Norwegian Journal of Geology 98, 1-17. https://dx.doi.org/10.17850/njg98-4-07. 


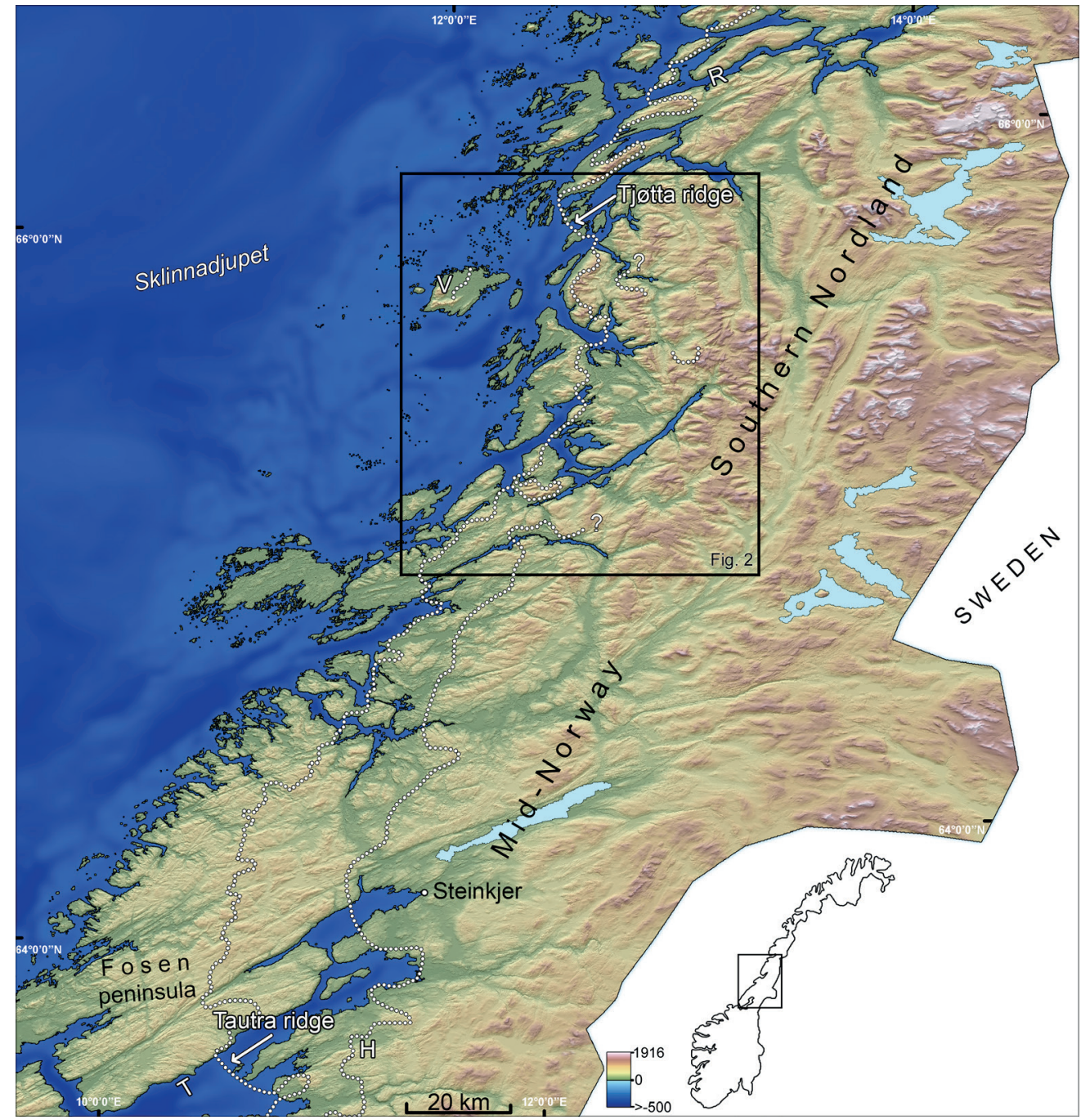

Figure 1. Regional setting. Dotted lines represent the approximate Scandinavian Ice Sheet position during the Tautra/Tjøtta event (outer line) - and the Hoklingen event (inner line), interpreted as early and late YD positions, respectively. Locations: $R$ - Ranfjorden, $V-V e g a, H$ - Lake Hoklingen (type locality), T - Trondheimsfjorden. The background maps in Fig. 1 and Fig. 2 are made by combining the GEBCO_2014 Grid (version 20150318, www.gebco.net) with a 10 m DEM from the Norwegian Mapping Authority (Kartverket).

ice-marginal deposits in a high-relief fjord environment. In other parts of Norway, the ice sheet readvanced considerably during the YD (Vorren \& Plassen, 2002; Bergstrøm et al., 2005; Mangerud et al., 2016). Different sectors of the Scandinavian Ice Sheet experienced different responses to the climatic forcing during YD (e.g., Mangerud et al., 2011; Gump et al., 2017) and although Andersen et al. (1982) suggested a major icesheet regrowth in the southern Nordland region, clear evidence has been missing up to now.

Here, we present observations from glacial geomorphology mapping from both onshore and offshore, based on high-resolution topographic and bathymetric data, along with 18 new radiocarbon dates from mollusc shells found in glacio-isostatically raised marine and glaciomarine deposits. The landform record comprises large ice-marginal features in the fjords and prominent end moraines onshore. Sub-till glaciomarine sediments onshore hold shells dated to the Allerød Interstadial and show that the outer fjord region was ice-free at least 5 $\mathrm{km}$ inland to the end moraines prior to the YD ice-sheet readvance.

\section{Regional setting}

Our focus has been on the mapping of ice-marginal features in and adjacent to the two fjords, Velfjord and Ursfjord (Fig. 2). The area is located south in Nordland county, where an alpine topography inland meets flat lowlands at the coastline. This coastal lowland, which is characterised by shallow waters with thousands of small islands and reefs, has been termed the strandflat (Reusch, 1894 ) and is at its widest in this region, stretching as far as $50-60 \mathrm{~km}$ seawards of the mainland (Holtedahl, 1998; Olesen et al., 2013). The marine limit rises from $100 \mathrm{~m}$ above present-day sea level at Vega to above $140 \mathrm{~m}$ asl. 


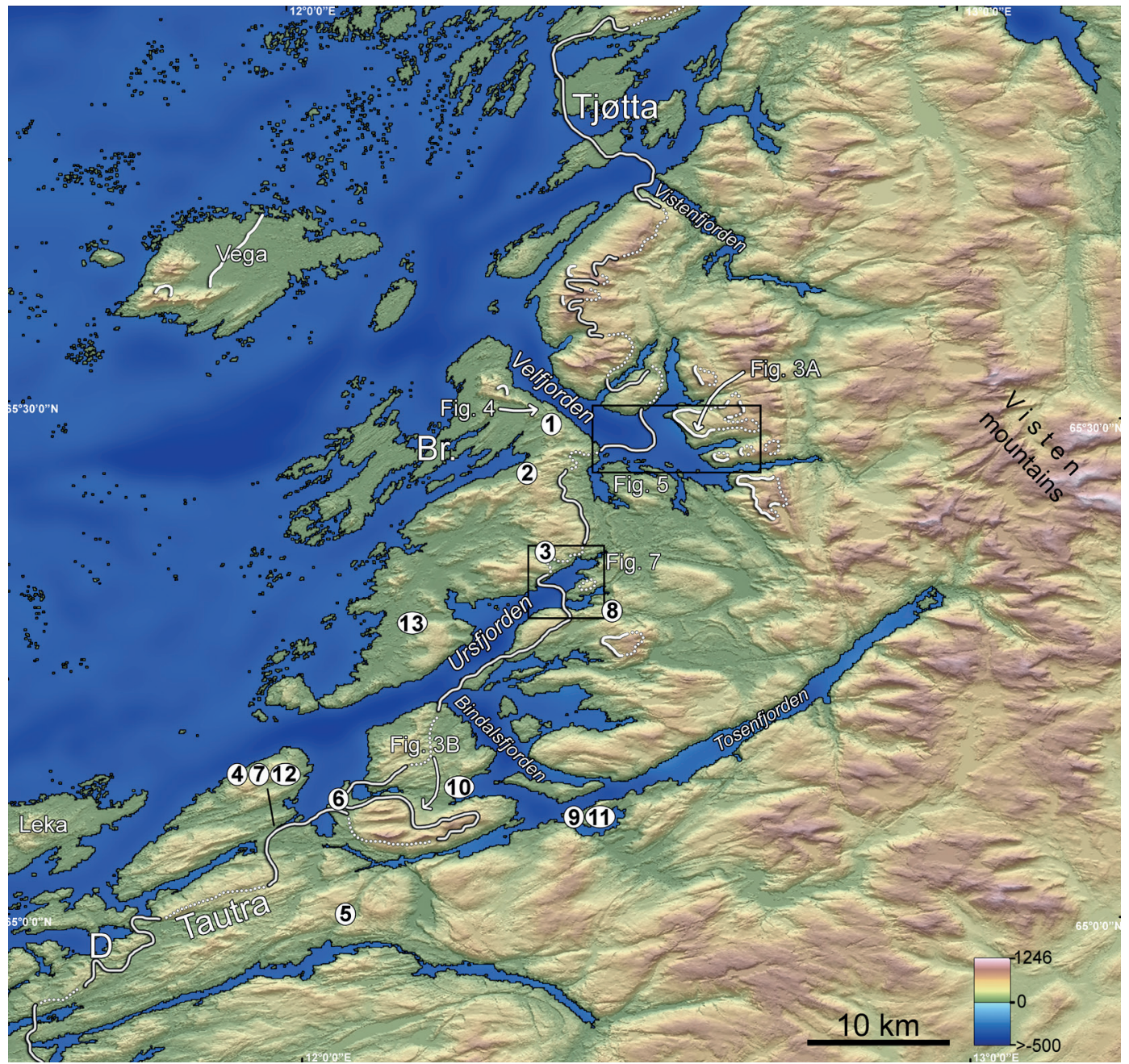

Figure 2. Study area. The solid and dotted lines represent mapped ice-marginal deposits and inferred position of the Scandinavian Ice Sheet during the Tautra/Tjøtta event. The moraine line on Vega represents an older substage, whereas the smaller, curved lines depict cirque glacier moraines. Numbering refers to radiocarbon dated sites described later in the text. Locations: Br - Brønnøyund, D - Djupvika.

in the inner fjord regions, implying that most of the coastal lowlands were situated below sea level during deglaciation.

The fjords in the region are deep troughs penetrating inland from the low-relief, coastal strandflat (Fig. 2). Depths of 400-700 $\mathrm{m}$ are common, adding to the 500$1000 \mathrm{~m}$ high mountains that are surrounding the fjords. The fjord basins are glacially eroded, over-deepened troughs and are typically separated from the strandflat by a bedrock sill at less than $200 \mathrm{~m}$ depth. The fjords acted as effective ice discharge troughs during Quaternary glaciations, evacuating large volumes of ice from the inland to the lower coastal region. Offshore, seafloor morphology reveals that ice-streams converged and flowed westwards towards the outer shelf break (Ottesen et al., 2005a), where vast glacial depocentres determine the ice sheet's former maximum extent (Sættem et al., 1996; Dahlgren et al., 2002).

\section{Methods}

\section{Glacial geomorphology mapping and marine bathymetry data collection}

Onshore, ice-marginal features were identified using airborne LiDAR-derived elevation data, in combination with aerial photographs and field reconnaissance. The high-resolution LiDAR data were processed into a $1 \mathrm{~m}$ (pixel size) digital elevation model (DEM), which was subsequently used to create shaded relief images with solar azimuths of $45^{\circ}, 315^{\circ}$ and $360^{\circ}$ and a solar angle of $45^{\circ}$. Distinct raised shorelines - ancient shoreline levels raised by glacio-isostatic adjustment following deglaciation - were observed in the field and further traced and correlated over a large area using the aerial photos and shaded relief images. 
Based on our onshore mapping of raised shorelines and ice-marginal features, we identified plausible calving front locations in Velfjorden and Ursfjorden. During a cruise with the research vessel "Seisma" in the autumn of 2016, high-resolution swath bathymetry data were collected from Velfjorden. Bathymetric data from inner Ursfjorden were acquired from the Norwegian Mapping Authority (Kartverket).

Bathymetric soundings in Velfjorden were performed using a Kongsberg EM-2040 dual-head multibeam echo-sounder system. Depths (sound velocity) were calibrated with a SVP (sound velocity profiler) prior to data collection. The survey was monitored using Olex AS (www.olex.no) software. The high-resolution data from Velfjorden generally allowed processing of a 1-metre digital bathymetric model (DBM) grid, while the data in Ursfjorden were sufficiently detailed to process a 5-metre grid. DBMs were gridded in Fledermaus DMagic, whereas subsequent computing of hillshade images and geomorphological mapping were carried out in ESRI ArcMap. Due to national confidentiality regulations with regard to high-resolution marine bathymetry, we are only allowed to depict small stamps of bathymetric data. All depth data in this paper are presented in metres below present-day sea level (m bsl).

\section{Radiocarbon dating}

All radiocarbon ages were obtained from marine mollusc shells. Older dates from Marthinussen (1962), Andersen et al. (1981) and Bargel (2003) that are relevant to this study have been calibrated and are listed along with the new dates (Table 1).
Radiocarbon ages were calibrated using the OxCal 4.2 calibration software (Bronk Ramsey, 2009) with the MARINE13 dataset (Reimer et al., 2013). Ages are given with a $2 \sigma$ (95.4\% probability) confidence interval and an $\mathrm{OxCal}$ derived weighted mean. All samples have been corrected for regional marine reservoir age by applying a $\Delta \mathrm{R}$ value of $71 \pm 21$, equal to a marine reservoir age of $412 \pm 18$ years. The value represents the reservoir age for coastal waters in northern Norway today (Mangerud et al., 2006). The reservoir age was likely 200-300 years higher during the YD, but similar to present-day values during the Bølling-Allerød Interstadial (Bondevik et al., 2006). All samples from former studies that were processed in Trondheim ( $\mathrm{T}$ or $\mathrm{TUa}$ ), except sample T-124 from Marthinussen (1962), were originally reported with a reservoir age correction of 440 years. This value had thus to be added back before calibrating the dates into calendar years.

\section{Results and interpretation}

\section{Ice-marginal features and raised shorelines}

We have identified ice-marginal features throughout the study area and morpho-stratigraphically correlated the previously established Tautra (Reite et al., 1982; Bargel, 2003; Olsen et al., 2015) and Tjøtta (Andersen et al., 1982) glacial events (Fig. 2). The mapping is part of a Quaternary geology mapping programme being carried out in the region (e.g., Høgaas et al., 2018a, b). The ice margin reconstruction given in Fig. 2 is similar to the YD reconstruction suggested by Andersen et al. (1995) and Hughes et al. (2016).

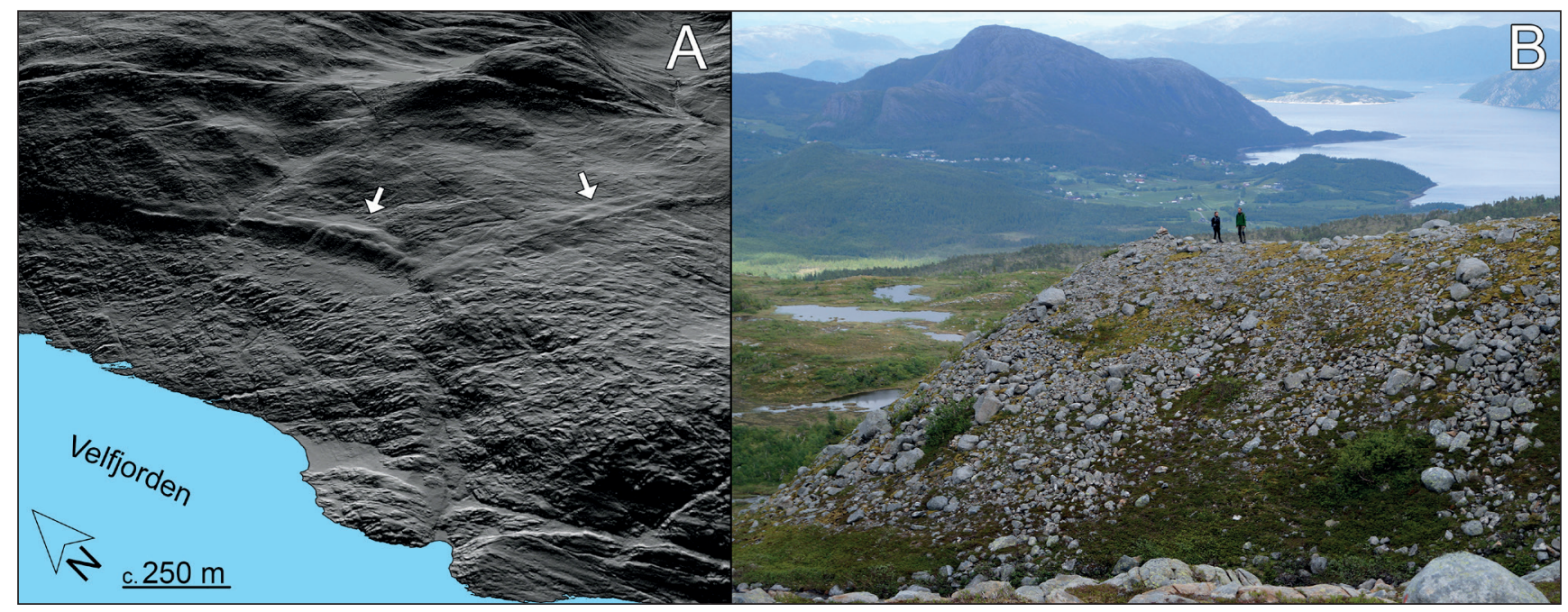

Figure 3. Examples of ice-marginal features in the region. (A) Oblique view of a LiDAR-derived hillshade image showing a large lateral moraine descending towards Velfjorden. The zone is 50-100 $\mathrm{m}$ wide, $>5 \mathrm{~m}$ high and the surface is scattered with large boulders. In aerial photographs the moraine stands out as a vegetated zone amid a rugged bedrock terrain. (B) A 15-20 m-high moraine ridge west of Bindalsfjorden. People for scale. View towards east-northeast. Photo: Anna Bergengren/Trollfjell geopark. 


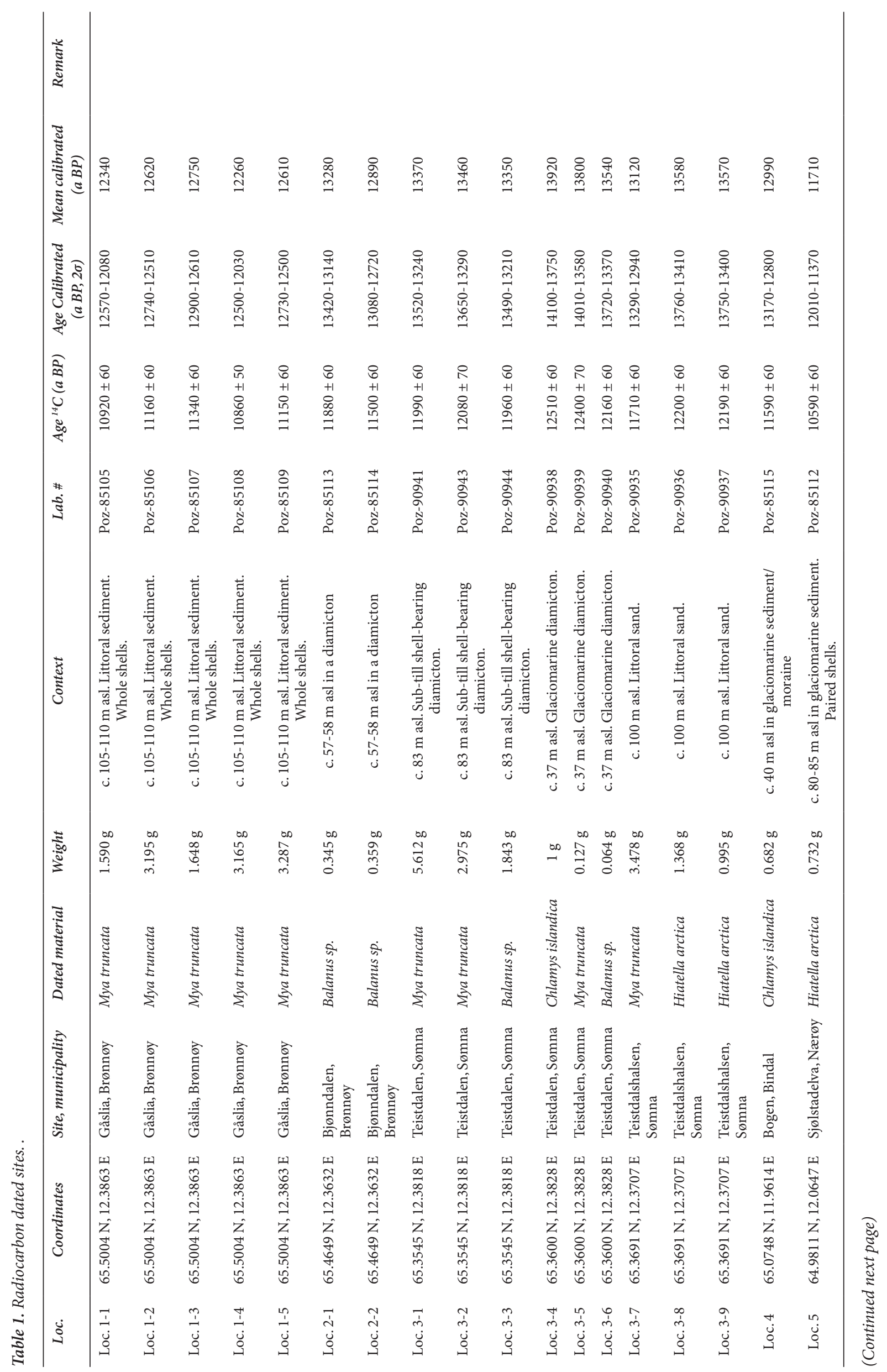




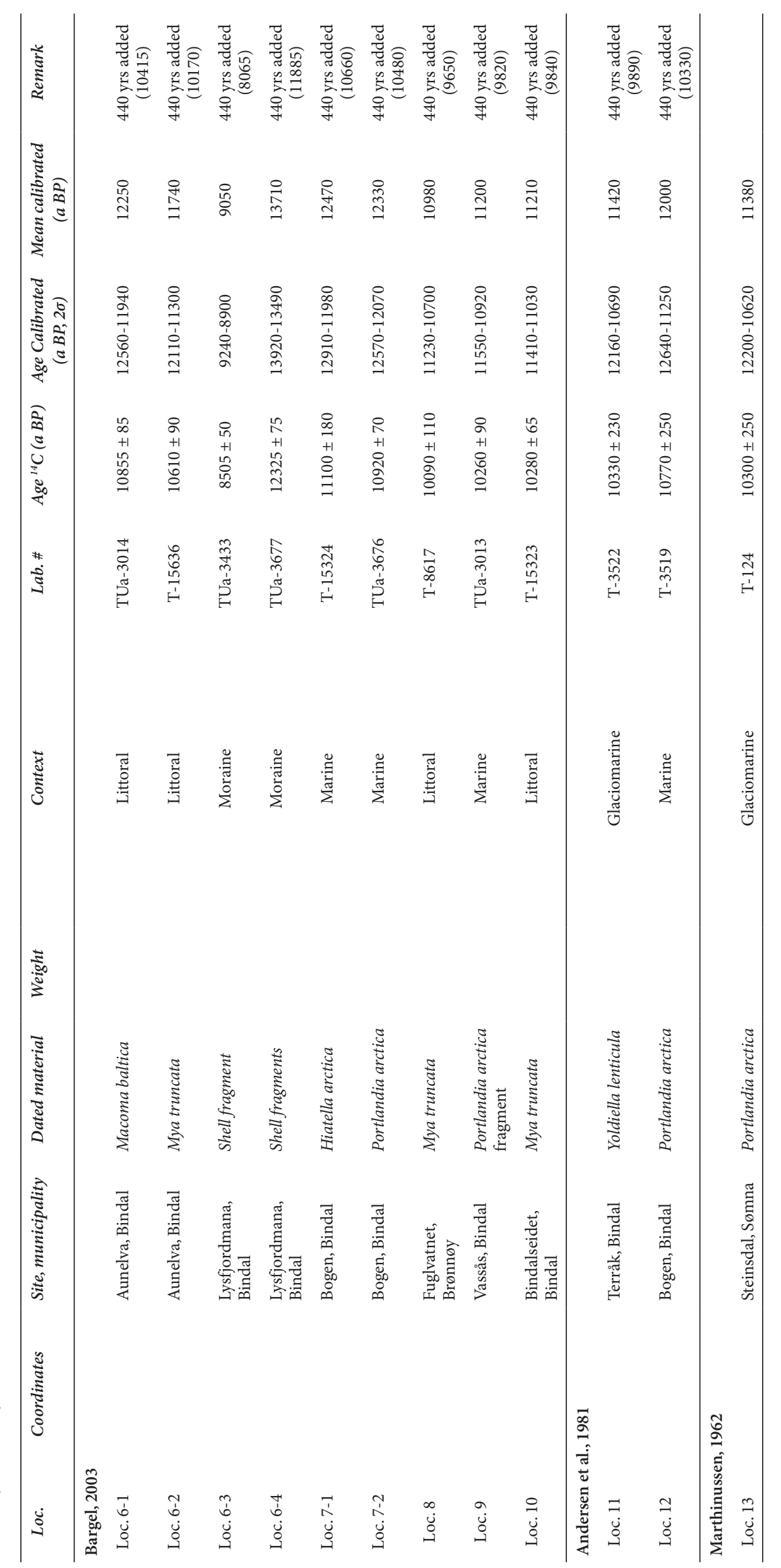




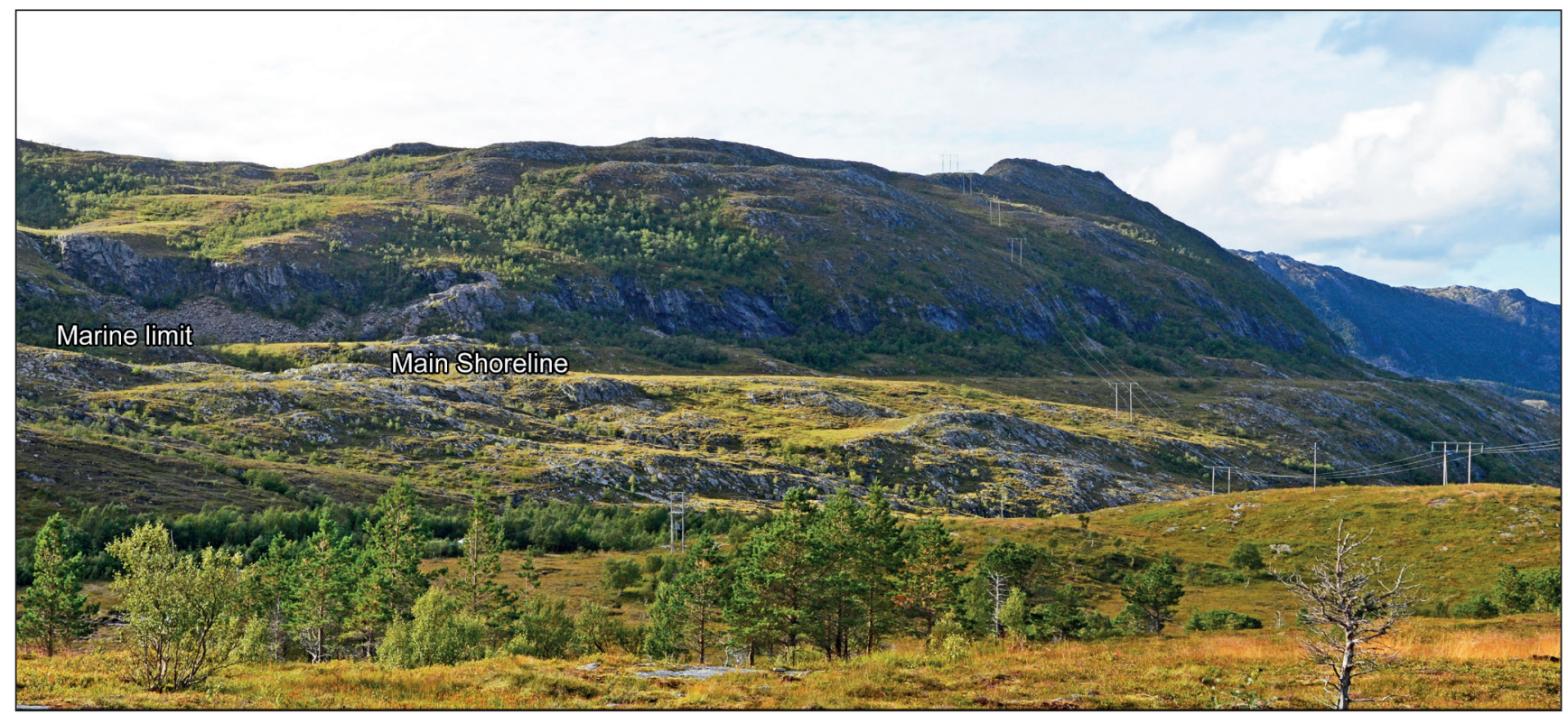

Figure 4. Marine limit (120-125 m asl) and the Main Shoreline (105-110 m asl) close to Brønnøysund. Powerline poles provide scale.

Large, sharp-crested, moraine ridges are common (Fig. 3), but the former ice margin is locally also characterised by more subdued boulder-rich deposits. Large end moraines were deposited by the inland ice sheet in the mountainous areas between Velfjorden and Vistenfjorden, whereas westerly-facing cirque glaciers nearby deposited local moraines just outside the YD inland ice-sheet limit. Cirque glaciers also deposited large local moraines on the island of Vega and in the outer part of Velfjorden (Fig. 2).

Raised shorelines represented by continuous lines eroded into bedrock (Fig. 4) are common features in the region (Rasmussen, 1981; Andersen et al., 1982; Høgaas \& Sveian, 2015). Shoreface erosion by frost weathering, freeze-thaw mechanisms and sea-ice abrasion in a tidal zone is thought to have formed the conspicuous shorelines (e.g., Andersen, 1968). The raised shorelines typically persist for several $\mathrm{km}$ at a time, often exceed 30 metres in width and are found as high as 120-130 $\mathrm{m}$ asl. in Velfjorden. The uppermost level - the marine limit shoreline - formed immediately following deglaciation and is the most distinct raised shoreline level in the region. In Velfjorden, however, the marine limit shoreline is dwarfed by the Main Shoreline of assumed YD age, which typically is situated $c .10 \mathrm{~m}$ lower in the terrain. Close to Brønnøysund (Figs. 2 \& 4), Main Shoreline sections are locally more than 40 metres wide and continuous for several $\mathrm{km}$. The Main Shoreline is continuous along most of the western side of Velfjorden, but is not found inside the inferred YD icemargin. From this we interpret that the raised shoreline and ice-front deposits were formed and deposited during the same period. This is a well-known principle in northern Norway, for instance, where raised YD glaciofluvial deltas are graded to the Main Shoreline level (e.g., Andersen,
1968). In Velfjorden, the ages of shells found at elevations close to the Main Shoreline (Loc. 1 below) support the interpretation of the shoreline being formed in the YD. Also, the post-YD climatic amelioration and rapid land emergence rule out a later formation of the lower shoreline.

\section{Bathymetric data}

The bathymetric data from Velfjorden reveal several prominent landforms (Fig. 5), that confirm our assumptions of the ice-margin location based on the onshore mapping. Most notably, a $1.5 \mathrm{~km}^{2}$ large sedimentary wedge - interpreted as a grounding-zone wedge (GZW) - is situated in the innermost part of this calving bay (Figs. $5 \& 6$ ). The asymmetric shape of the feature, with a conspicuous, steeper distal slope, along with the presence of glacial lineations on the surface, matches with the characteristics of GZWs described elsewhere (e.g., McMullen et al., 2006; Ottesen et al., 2008b; Dowdeswell \& Fugelli, 2012). The most proximal part of the GZW is found at $c .175 \mathrm{~m}$ bsl, in lee of a bedrock ridge. From here it rises steadily to $c$. $140 \mathrm{~m} \mathrm{bsl}$ at the frontal break, before it rapidly drops to under $200 \mathrm{~m}$ bsl. Long and sharp-crested crag-andtail landforms are present from the deposit's apex to the very front. The crag-and-tails all show a high elongation ratio (length:width ratio from 26:1 to 9:1). On the fjord bottom just distal to the GZW, large deposits of ravined sediments are seen (Fig. 6).

End moraines are mapped to either side of the GZW and are generally located a bit farther out in the fjord. North of the GZW, where a glacial lobe flowed out of the fjord branch and merged with the Velfjorden Ice 


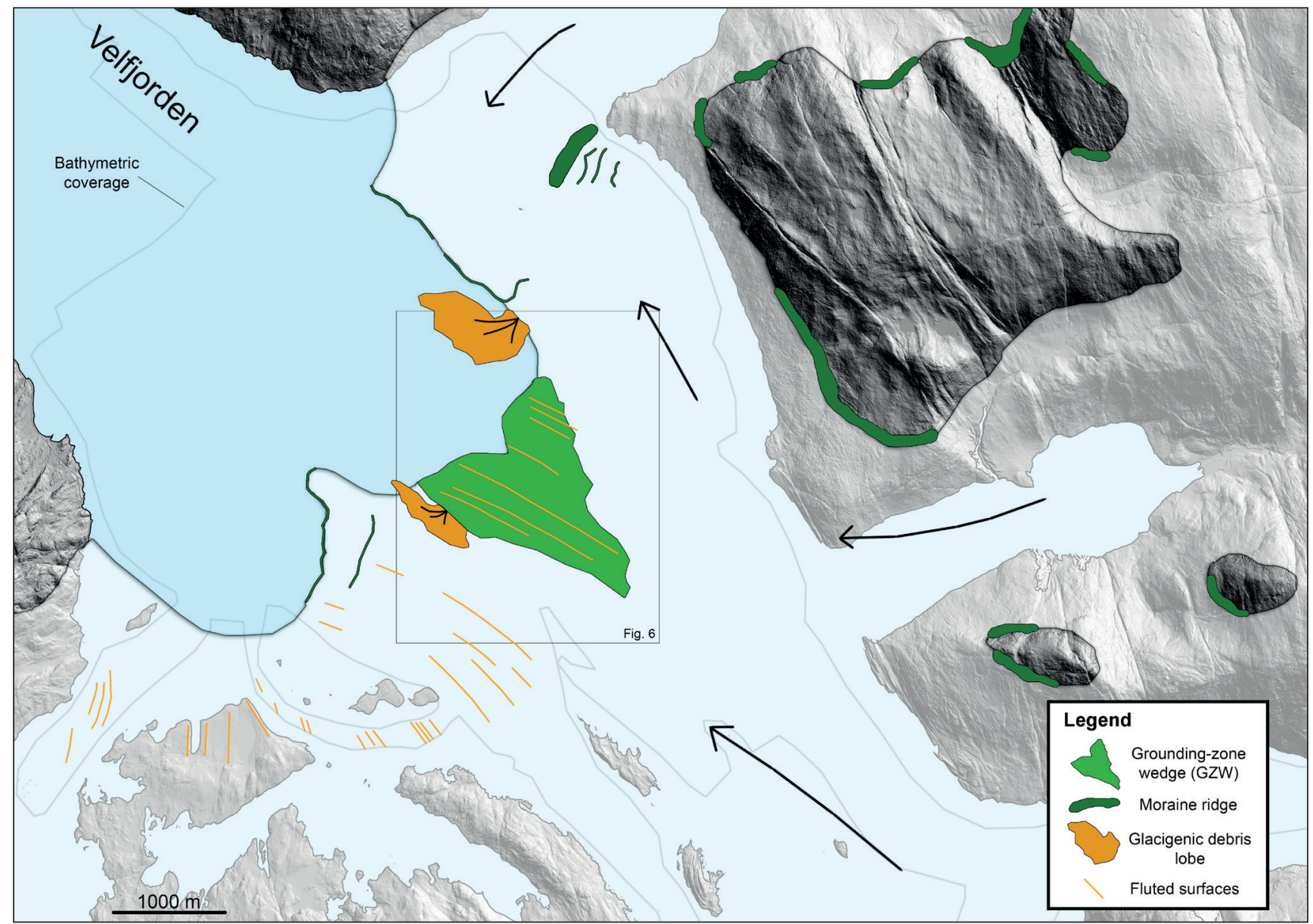

Figure 5. Mapped glacial landforms and inferred grounded ice-margin in Velfjorden. A small floating ice shelf may have reached some distance beyond this line.

Stream, we have mapped a broad ridge interpreted to represent a medial moraine. Alternatively, the moraine could represent a slightly younger stage during the deglaciation. The frontal part of the northern ice margin is an end moraine situated on top of a bedrock ridge. Large glacigenic debris lobes deposited just outside this ridge support the interpretation. To the west, we see two parallel end moraines. Here, several elongated drift landforms are also found both on- and offshore. The mapped landforms point to a rapidly streaming grounded outlet glacier with a calving margin. The highest-lying palaeonunataks are determined by lateral moraines found up to $800 \mathrm{~m}$ asl. c. $12 \mathrm{~km}$ inland of the GZW. Lateral moraines adjacent to the sedimentary wedge are found c. $150 \mathrm{~m}$ asl., which yields an average glacier front surface gradient of $>55 \mathrm{~m} / \mathrm{km}$.

In Ursfjorden, a large terminal moraine is found at $c$. $450 \mathrm{~m}$ bsl (Fig. 7). The ridge extends across the fjord at a bedrock confinement and towers up to $80-100 \mathrm{~m}$ above the fjord bottom (Fig. 8). Large drift landforms interpreted as Mega-Scale Glacial Lineations (MSGL) - are seen just inside the former ice margin. The end moraine has a consistent morphology across and rises steadily from c. $475 \mathrm{~m}$ bsl to $375 \mathrm{~m}$ bsl, before it drops down to the fjord bottom at c. $475 \mathrm{~m}$ bsl (Fig. 8A \& B). Along the eastern side of Ursfjorden, the ice margin was situated at or close to the fjord break, where depths drop from c. 100 to $500 \mathrm{~m}$ bsl over a short distance. Here, we can see that large fans, probably stemming from glacigenic debris flows, have formed in several places on the fjord bottom.

\section{Radiocarbon dated sites}

We present 18 new radiocarbon samples from the southern Nordland region, numbered in accordance with Table 1 and plotted in Fig. 2. We do not go into detail on Locs. 6-13, i.e., the dates from previous studies (Marthinussen, 1962; Andersen et al., 1981; Bargel, 2003).

Loc. 1 - Gåslia, Brønnøy - altitude 105-110 m asl., $65.5004 \mathrm{~N}, 12.3863 \mathrm{E}$

Along a small river bend at Gåslia, several whole shells and numerous smaller fragments have been exposed due to erosion of raised littoral deposits. We dated five Mya truncata shells to $c$. $12.9-12 \mathrm{cal} \mathrm{ka}$ BP. This site is located 


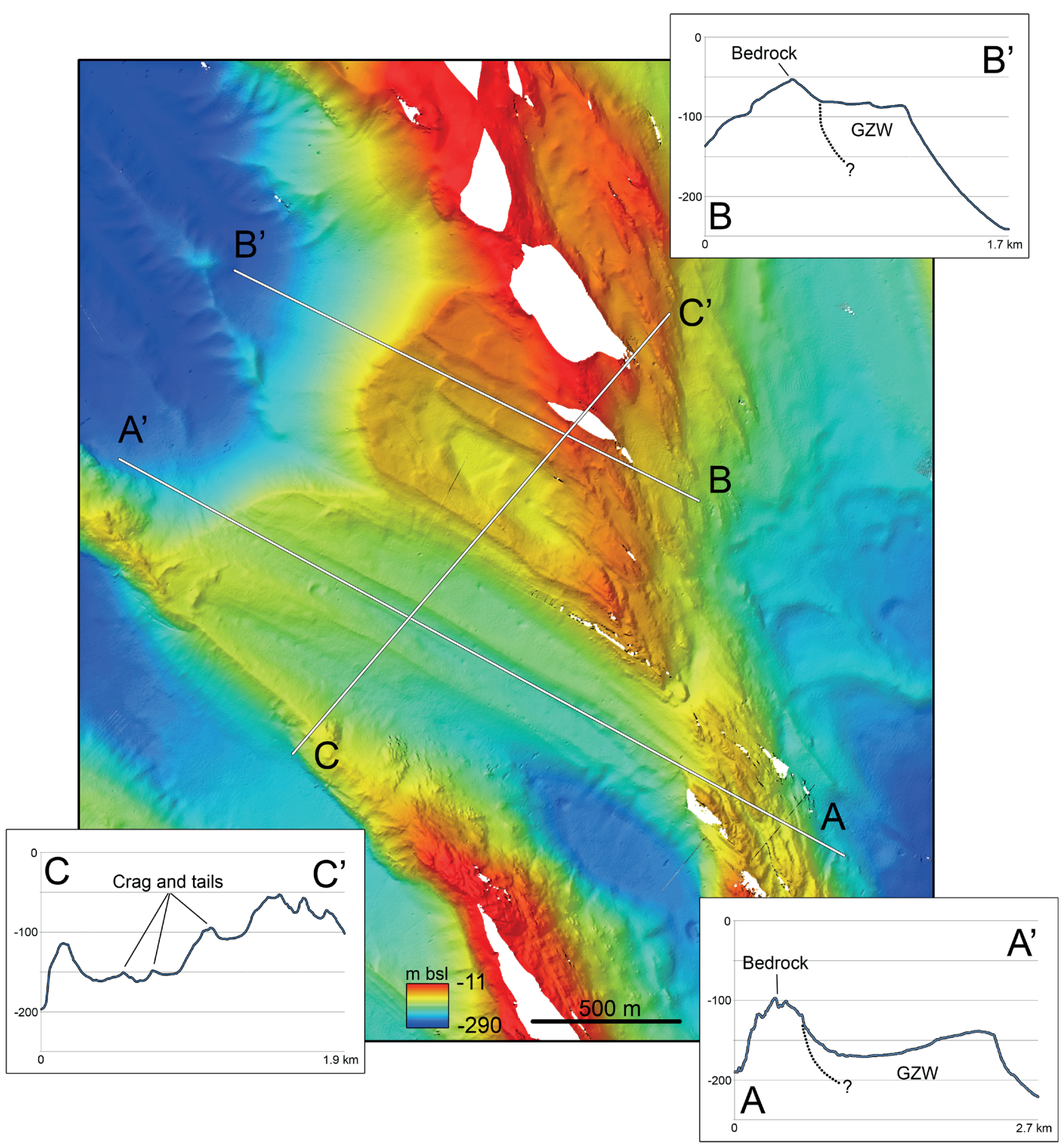

Figure 6. Bathymetric image of the grounding-zone wedge (GZW) in Velfjorden. The fan-shaped wedge is developed in the lee of a bedrock ridge. Glacial lineations on the surface reveal that the grounding zone was located at the very front of the ice-marginal feature.

close to the Main Shoreline, which disappears close to the inferred YD ice-margin.

Loc. 2 - Biønndalen, Brønnøy - altitude 57-58 m asl., $65.4649 \mathrm{~N}, 12.3632 \mathrm{E}$

Two dated samples of barnacles (Balanus sp.) found in a diamicton yielded c. 13.4-12.7 cal ka BP. We interpret the diamicton as a mixture of raised beach deposits and scree material, and ascribe the dated barnacles as originally stemming from the latter component, as these organisms usually live around the tidal level. The sea level around $13 \mathrm{ka}$ BP was probably c. 110-120 m asl. The dates are included here as indicators of minimumlimiting deglaciation ages for the outer coastal area.

Loc. 3 - Teistdalen, Sømna - 65.3586 N, 12.3801 E The sites are located c. $5 \mathrm{~km}$ north of the terminal moraine in Ursfjorden, where a glacial lobe flowed 


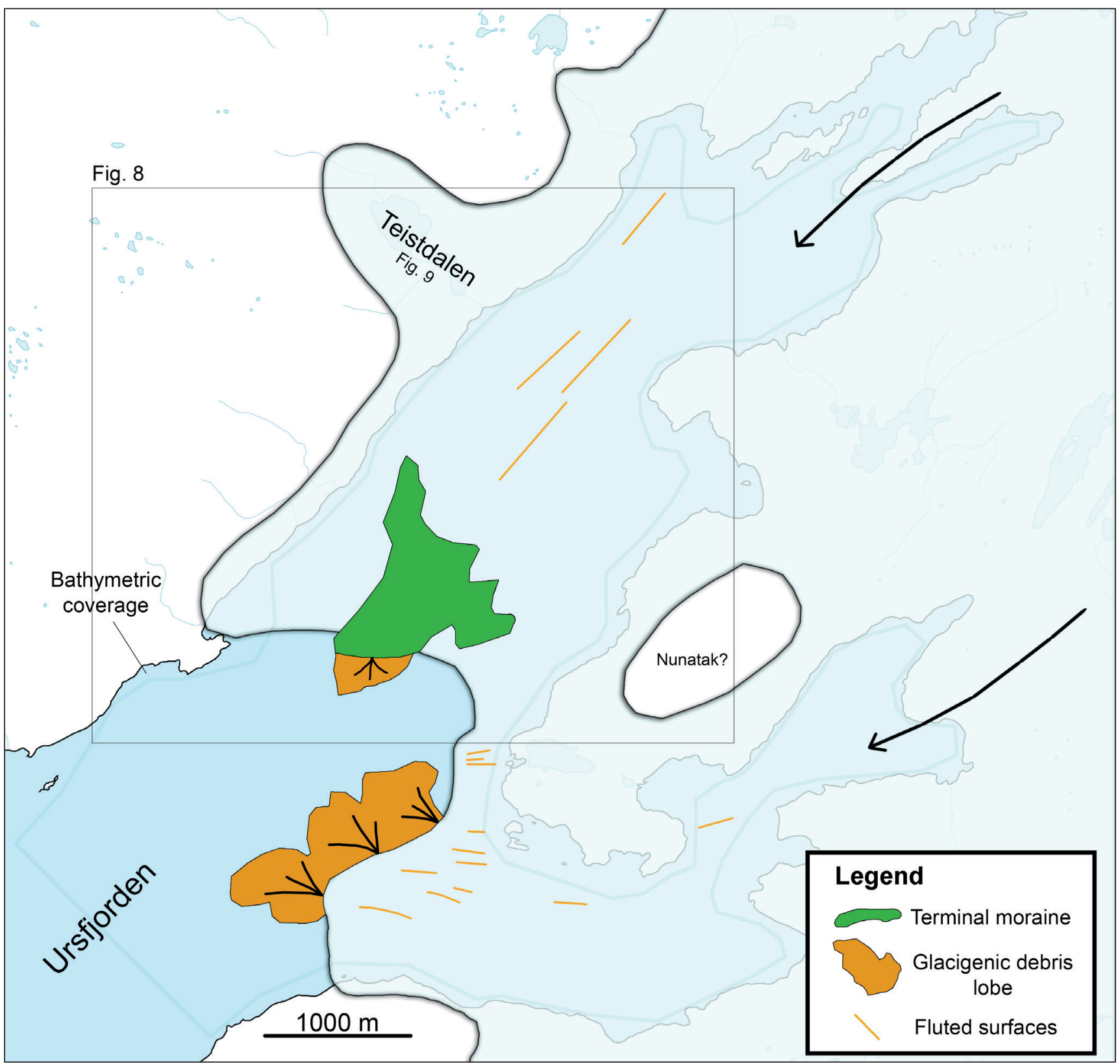

Figure 7. Mapped glacial landforms and inferred grounded ice-margin in Ursfjorden.

northwest into the Teistdalen valley. This led to glacial overriding of existing shell-bearing sediments and deposition of glaciomarine and diamict units. We have dated nine samples of shells from three different sites near the Teistdalen valley (Fig. 9). At the first site (c. $83 \mathrm{~m}$ asl.) three samples from an overridden diamicton yield $c$. 13.6-13.2 cal ka BP (Fig. 10). The second site is located at c. $37 \mathrm{~m}$ asl. and shows a glaciomarine diamicton over a compact till (Fig. 10). Here, three samples from the upper unit (samples 3.4-3.6) yield 14.1-13.4 cal ka BP. Northwest of the local drainage threshold and distally of the glacial advance, we have dated three samples from a shell-rich sublittoral unit at $c .100 \mathrm{~m}$ asl. (Fig. 10). The samples yield 13.8-12.9 cal ka BP, which indicates that the site was ice-free during YD. Similar to Loc. 2, these dates also serve as minimum-limiting deglaciation ages for the coastal area.

Loc. 4 - Bogen, Bindal - altitude c. $40 \mathrm{~m}$ asl., 65.0748 $\mathrm{N}, 11.9614 \mathrm{E}$

The Bogen locality is a part of the lobate frontal deposit belonging to the outermost part of the Tautra substage (e.g., Olsen et al., 2015). One fragment of Chlamys islandica was located in a glaciomarine unit and dated to $13.2-12.8 \mathrm{cal} \mathrm{ka}$ BP. Shell fragments from Bogen have also been dated by Andersen et al. (1981) and Bargel (2003), and the lobate frontal deposit is morphologically traceable over a large area (Fig. 2). 


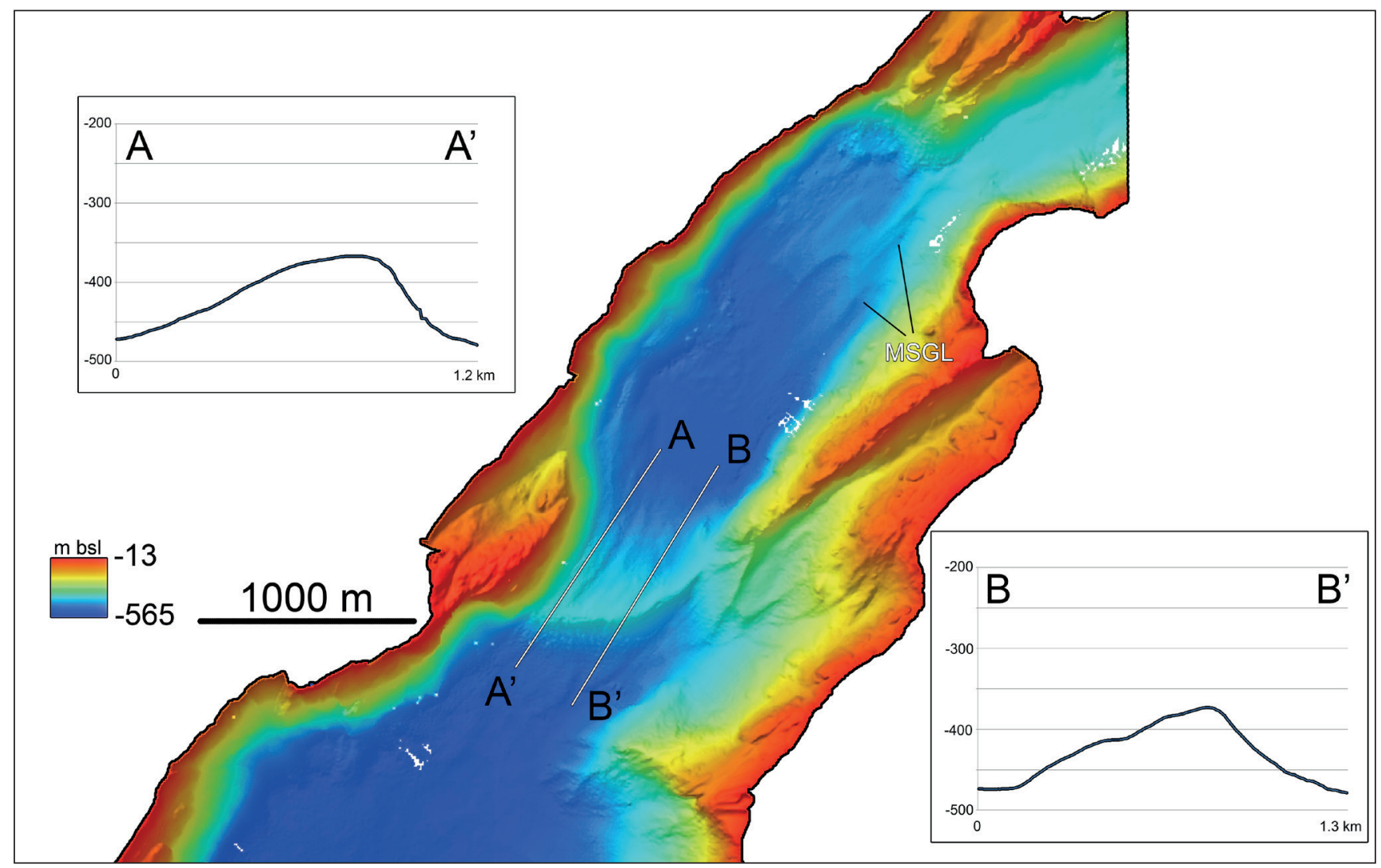

Figure 8. Bathymetric image of the terminal moraine in Ursfjorden. The large ridge rises to 100 metres above the sea floor at c. $450 \mathrm{~m} b s l$. The bathymetry was provided by the Norwegian Mapping Authority (Kartverket).

Loc. 5 - Siølstadelva, Nærøy - altitude $80-85$ m asl., $64.9811 \mathrm{~N}, 12.0647 \mathrm{E}$

South of outer Tosenfjorden, near the Sjølstadelva river, we identified whole and paired mollusc shells and several shell fragments in a glaciomarine unit. One of the shells - a fragment of a paired Hiatella arctica shell - was dated to $12-11.4 \mathrm{cal} \mathrm{ka}$ BP. The shells were located $>40$ $\mathrm{m}$ lower than the local marine limit, but the amount of paired and whole shells in the sections argue against resedimentation to a lower topographical level.

\section{Discussion}

\section{Characteristics and distribution of ice-marginal features}

The bathymetric data show the presence of very large submarine ice-marginal features in Velfjorden and Ursfjorden. The ice sheet also deposited large moraine ridges in the mountainous terrain between the studied fjords, testifying to a significant contemporaneous push along the entire ice-sheet margin during the glacial event. The glacier front in Velfjorden likely advanced to a hinge point (bedrock ridge) before gradually building the GZW seawards during a grounding-line advance. The lineations on top of the GZW support the interpretation of large-scale transport of glacigenic debris to the very front of the feature. GZWs are sedimentary depocentres, where deformation till is continuously transported towards the frontal break in a sediment conveyor belt (Anandakrishnan et al., 2007). Here, the till can be deposited by sediment gravity flows, which are seen as dipping structures in seismic profiles (Batchelor \& Dowdeswell, 2015). The internal structure of the GZW in Velfjorden is unknown, but the morphological conformity with GZWs elsewhere allow us to assume a similar development. The ravined sediment on the fjord bottom distal to the GZW, may stem from settled sediment plumes related to the GZW build-up. The sediment may also be related to the deglacial phase prior to the YD main event and GZW build-up, but as yet the origin is not fully understood.

We believe the glacier front in Ursfjorden advanced across the inner subbasin (Fig. 8), before coming to a halt where the fjord is narrowest, where the terminal moraine was formed. Distal to this, there is a slight widening of the fjord. At the contemporary depth of almost $600 \mathrm{~m}$, it would take a substantial support to prevent calving and disintegration of the glacier snout. The moraine was probably formed by a continuous feed of deformation till towards the snout with subsequent gravity flows on the distal side. This architectural build-up has been 


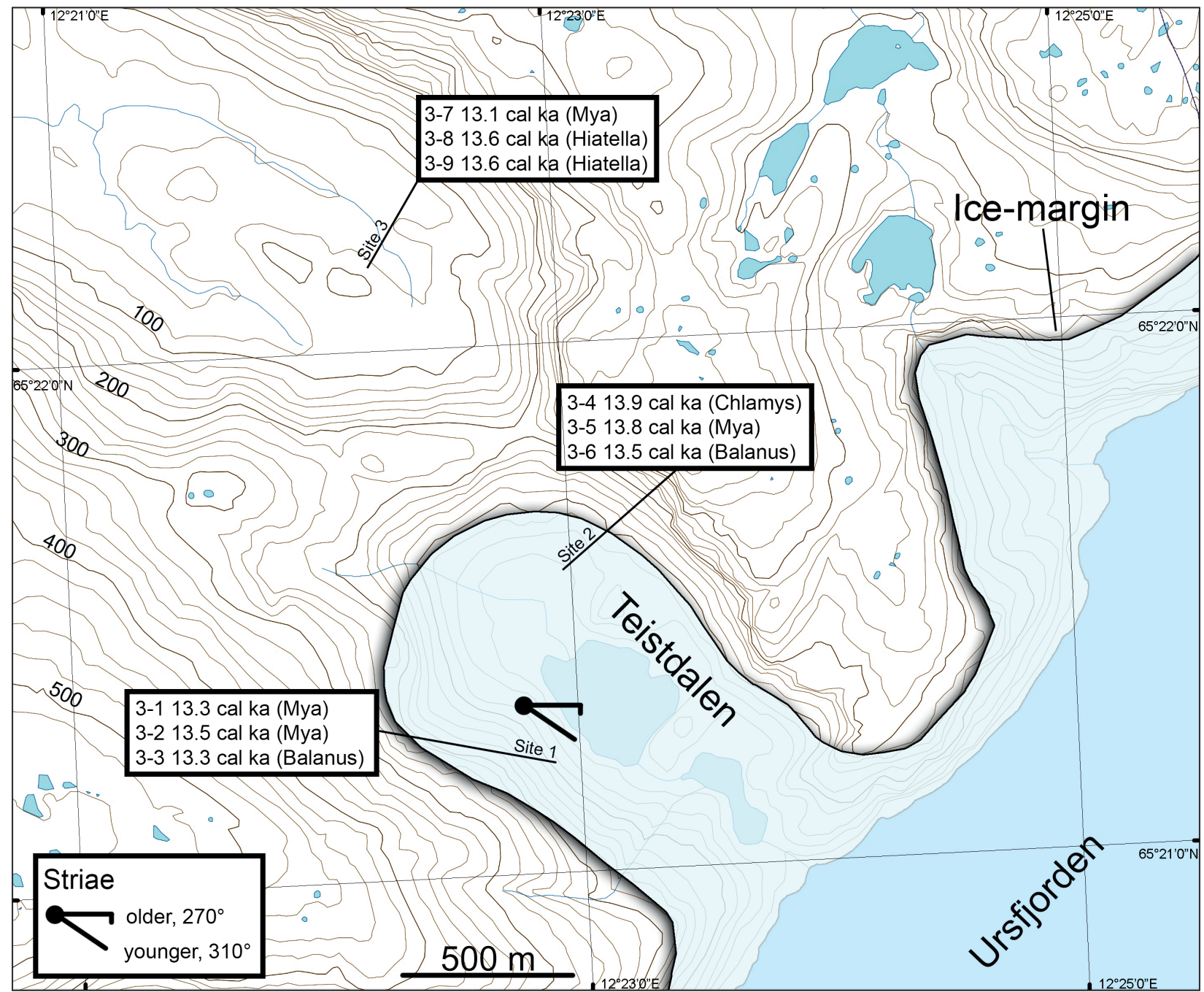

Figure 9. Map showing the different locations in Teistdalen (Loc. 3; Fig. 2) in relation to the approximate YD ice-marginal zone. The area is located just a few km proximal to the submarine terminal moraine in Ursfjorden (Fig. 7). Lithostratigraphic logs from the sites are shown in Fig. 10.

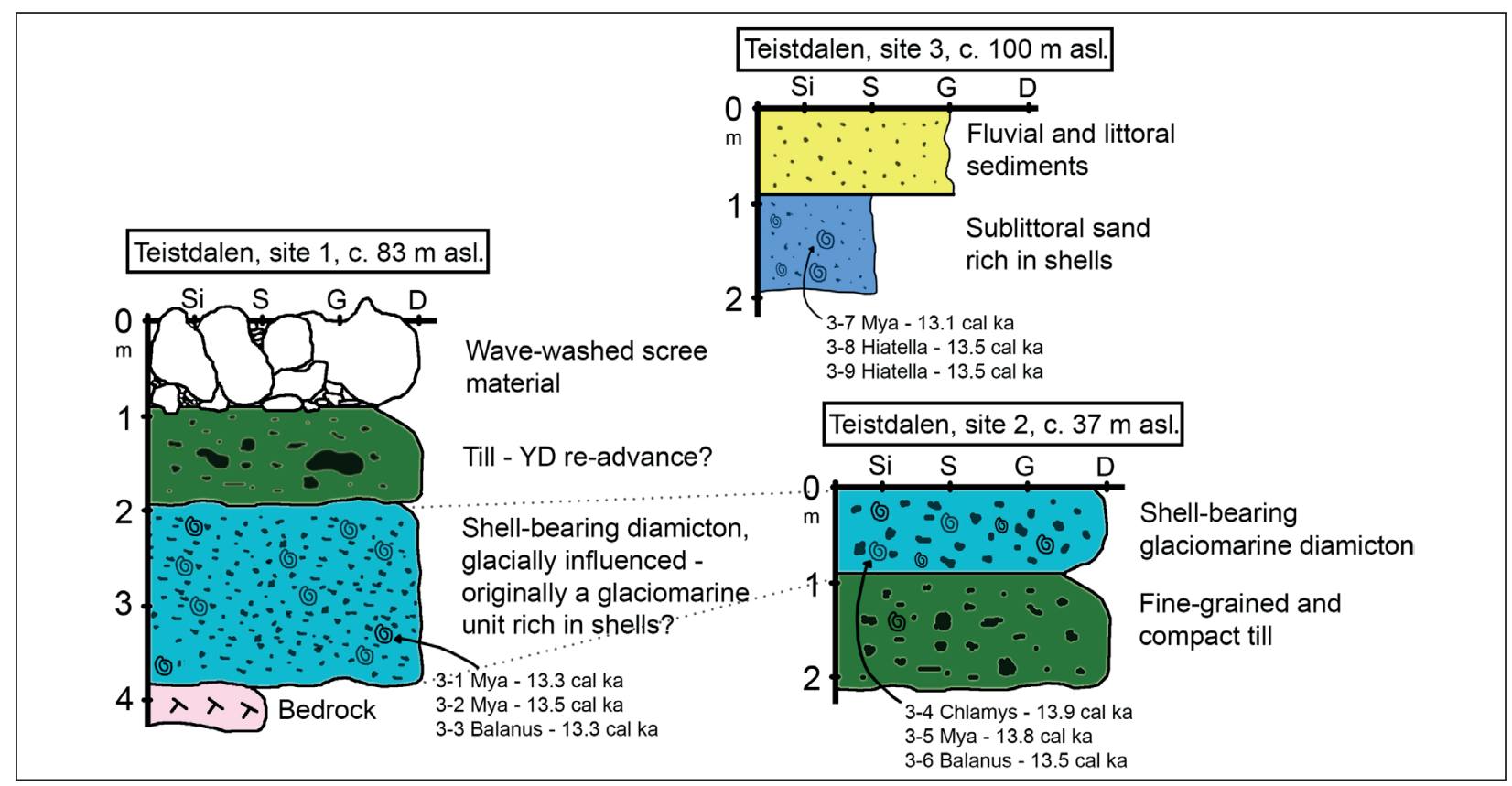

Figure 10. Lithostratigraphic logs from sites 1,2 and 3 in and near Teistdalen (Fig. 9). A likely correlation between the units at sites 1 and 2 is indicated with dotted lines. 


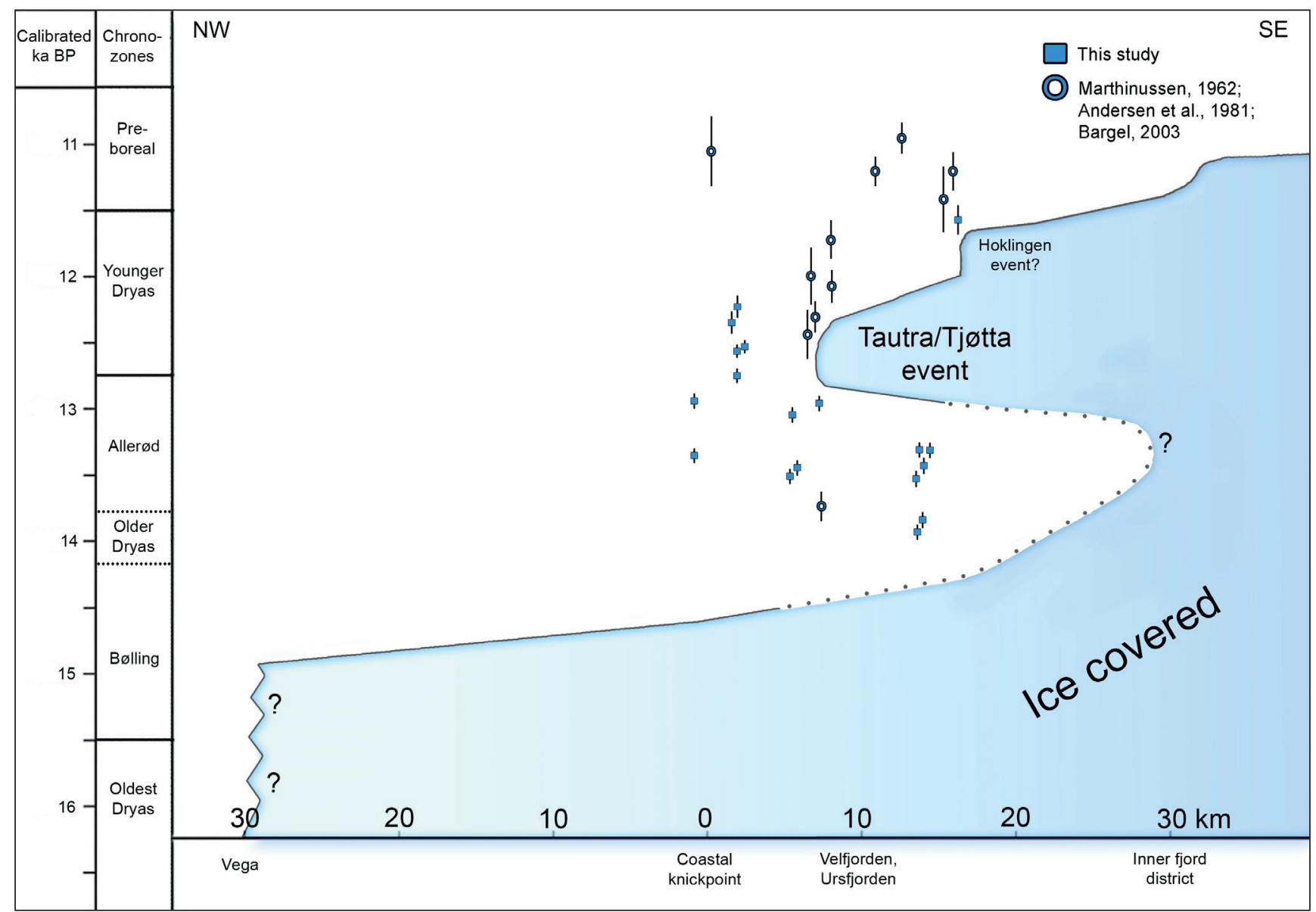

Figure 11. Tentative time-distance diagram for the ice-margin in southern Nordland, showing ice cover and the mean calibrated ages presented in Table 1. Error ranges are based on the 68.2\% (1 $\sigma)$ confidence interval. One date (Loc. 6-3; TUa-3433) was too young to be plotted on this diagram. Adapted from Mangerud et al. (2011).

reported from seismic studies on late glacial ice-marginal deposits in northern Norway and Svalbard (Andersen et al., 1982; Lyså \& Vorren, 1997; Ottesen \& Dowdeswell, 2006; Ottesen et al., 2008a). The large glacigenic fans seen on the eastern fjord break in Ursfjorden are common features where glaciers are unable to advance into deep fjord basins situated beyond the margin (e.g., Lyså \& Vorren, 1997). The very presence of the fans indicates a high delivery of meltwater and sediment towards the glacier front.

Submarine MSGL and swarms of fluted bedrock are seen near the former ice-margin. Fluted bedrock surfaces are also seen on-land in the LiDAR-derived shaded relief images. The landform record in the studied fjords points to a rapidly streaming, warm-based glacier front with a deformable bed and is in accordance with morphological characteristics of palaeo-ice streams elsewhere (e.g., Stokes \& Clark, 1999; King et al., 2009; Eyles, 2012; Stokes et al., 2015; Krabbendam et al., 2016).

\section{Regional deglaciation}

A tentative reconstruction of the regional deglaciation pattern is presented as a time-distance diagram in Fig. 11, representing a transect from coast to inland. The reasoning for our approach to the older phase is as follows. Andersen et al. $(1981,1982)$ presented a dated shell fragment from the broad, wave-washed Vega Moraine (Fig. 1) which yielded c. 16 cal ka BP (T-3941: $13,420 \pm 170{ }^{14} \mathrm{C}$, calibrated $\left.16,660-15,600\right)$, but assumed the date was too old. Instead, he argued that the Vega moraine rather correlated to an ice-marginal zone deposited at around $14.2 \mathrm{cal} \mathrm{ka} \mathrm{BP.} \mathrm{In} \mathrm{contrast,} \mathrm{if} \mathrm{the}$ date does reflect the deglaciation of Vega, it is correlative with glacial events of $c$. 16-15 cal ka BP age suggested from studies farther north (Ottesen et al., 2005b; Laberg et al., 2009, 2017). Deglaciation of the outer coastal islands occurred prior to $14 \mathrm{cal} \mathrm{ka} \mathrm{BP}$, as we have dated multiple shell fragments to $14-13.5$ cal ka BP $30 \mathrm{~km}$ inland of Vega. In addition to this, bones from a bowhead whale (Balaena mysticetus) found a few $\mathrm{km}$ northwest of Teistdalen (Fig. 2) yielded $13.1 \mathrm{cal} \mathrm{ka} \mathrm{BP} \mathrm{(Mathisen,}$ 
1987 , p. 30). This indicates fully ice-free conditions in the outer fjord districts in the warm Allerød Interstadial. Unfortunately, we have not been able to locate any information concerning lab number related to the whale bone find, or if the date has been corrected for local reservoir age.

Studies just south of our study area suggest that the Older Dryas (OD, c. 14 cal ka BP) ice-marginal zone generally is found close to (e.g., in Djupvika; Fig. 2), or even inside of, the YD maximum position (Bargel et al., 1994; Olsen et al., 2015). This relationship between the OD/YD ice-margin positions is also seen in western Norway (Mangerud et al., 2016, 2017). Because of the close positioning of OD/YD ice-marginal zones a short distance to the south, it is unlikely that the ice sheet advanced beyond the deep fjords and the strandflat to reach Vega at around $14 \mathrm{cal} \mathrm{ka} \mathrm{BP}$. We conservatively suggest that deglaciation of Vega and the outer coastal islands took place between $c .16$ and $14.5 \mathrm{cal} \mathrm{ka} \mathrm{BP.} \mathrm{We}$ stress, however, that this interpretation is uncertain and that more research is needed to constrain the deglaciation chronology of this area.

No ice-marginal features have been found among the strandflat shallows and reefs between Vega and Brønnøysund (Fig. 1). The YD ice-marginal zone is located c. 10-15 km farther inland. Shells found close to the Main Shoreline in Velfjorden provide an age of 12-12.9 cal ka BP (2 $\sigma$ interval - Loc. 1) for the ice margin. The shoreline grades into the former glacier terminus and is not found beyond this point (Fig. 12). We cannot rule out that the shells have been redeposited to a lower topographic level, but this is contested by the large number of whole shells found in the section. The rest of our radiocarbon dates found in relation to the YD moraines (Locs. 3 \& 4) generally give too old ages. These shells are found incorporated in moraines or belong to units that are located stratigraphically beneath the YD readvance. The old ages are thus due to resedimentation or glacial overriding of existing

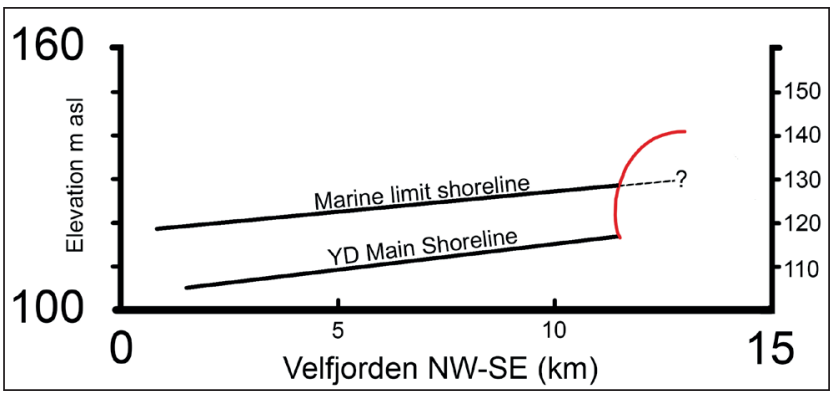

Figure 12. Schematic shoreline diagram from the middle to inner part of Velfjorden, with inferred ice-margin position. The difference in altitude between the two shorelines is c. 10 metres, but decreases gradually towards the inner parts of the fjord. Note that the diagram is not drawn perpendicular to the regional uplift isobases. material. Reworking also serves to explain the $13.7 \mathrm{cal}$ ka old shell found incorporated in a moraine ridge of assumed YD age by Bargel (2003). We have no basis to reject the work done adjacent to our area (Andersen et al., 1982; Olsen et al., 2015) and believe the ice-marginal zone and large deposits mapped in this study represent the YD maximum. Rather, the dates illustrate well the uncertainty involved in collecting and dating shells found in relation to ice-marginal deposits. Performing a thorough regional assessment is hence pivotal to understanding the full deglaciation picture.

The maximum position of the Scandinavian Ice Sheet during the YD occurred time-transgressively throughout Norway (e.g., Mangerud et al., 2016) and an early YD maximum, like we see in Mid Norway (Olsen et al., 2015), differs from other regions. In western Norway, the ice sheet readvance culminated late and did not retreat until close to the Younger Dryas/Holocene boundary (Bondevik \& Mangerud, 2002; Lohne et al., 2012). The equivalent event in mid-Norway is termed the Hoklingen substage (Fig. 1) and is more pronounced south of Trondheimsfjorden (Reite et al., 1982; Olsen et al., 2015). In northern Norway a mid to late YD age has been proposed for the maximum position (Vorren \& Plassen, 2002; Bergstrøm et al., 2005; Romundset et al., 2017). Our data suggest an early to mid-YD age for the ice-marginal features mapped in this study, but we are unable to fully resolve the timing of the ice sheet's maximum position during the YD chronozone in southern Nordland. Taking into account the large uncertainty related to the context of dated material, plateaus in the radiocarbon calibration curve, as well as variable marine reservoir ages, achieving accurate ages of the Lateglacial ice-margin position based on ages of molluscs found in relation to proglacial sediments, is at best challenging. This is particularly true in the case of a glacier readvance, as it often implies extensive reworking of existing material. A complementary approach to understand the deglaciation chronology further, would be to investigate threshold basins, which has proved successful in other parts of Norway (e.g., Selnes, 1982; Bondevik \& Mangerud, 2002; Lohne et al., 2012) and to identify geochronological markers, such as tephra horizons, in continuous sediment archives (e.g., Mangerud et al., 1984; Koren et al., 2008; Lohne et al., 2013).

Small ridges on and near the GZW in Velfjorden may indicate the first signs of a retreat from the maximum position. From there, we believe the ice sheet retreated rapidly to Tosenfjorden, as there are no ice-marginal deposits that indicate temporary still-stands in between. The small notches seen after the YD maximum event (Fig. 11) represent tentative minor and short-lived halts in the general ice-sheet recession, which are seen as large lone-standing ice-marginal deposits, e.g., in Tosenfjorden (Bargel, 2003). Of these, one could be correlated with the late YD Hoklingen event described from the Trondheimsfjord region (see Fig. 1; Reite et al., 1982; Olsen et al., 2015). Our mean calibrated ages indicate a 
late YD-early Holocene deglacial age for the sites located inside the YD maximum zone (Fig. 11; Table 1; Locs. 5, $8,9,10 \& 11$ ), but some of the dates may be somewhat younger than the local deglaciation.

The raised shorelines are good indicators of ice-free conditions. Both the marine limit shoreline and the YD Main Shoreline disappear close to the YD ice-marginal deposits in Velfjorden (Fig. 12). This testifies to ice-free conditions in the fjord prior to the YD glacial event and that the fjord was ice-free at least to the same extent as when the Main Shoreline was formed, but it is unknown precisely when the marine limit shoreline formed.

\section{Is there evidence of a Younger Dryas ice-sheet readvance?}

There are several circumstances that point to a YD icesheet readvance in southern Nordland, but only one that establishes that such an advance occurred. The distribution of marginal moraines suggests that the ice sheet advanced significantly uphill in many areas, e.g., deposited large end moraines at more than $350 \mathrm{~m}$ asl. west of Bindalsfjorden (Fig. 3B) and 500-700 m asl. north of Velfjorden (Fig. 2). In the case of a prolonged or temporary ice-sheet stand-still, ice-marginal features would have been much more topographically confined to topographical lows. Also, the continuity, size and morphology of both submarine and terrestrial icemarginal features attest to an ice-sheet advance, and that this occurred along the entire studied margin.

Drift landforms and abrasion of bedrock reflect fast ice flow towards the margins of the ice sheet. The ice transport direction inferred from the mapped landforms differs from the regional direction related to earlier phases of the glaciation, but such landforms are not unequivocally related to an advancing ice-margin.

Shells dated to the Allerød Interstadial that are overrun and incorporated in diacmictons within the YD terminal zone, constitute the sole evidence of an ice-sheet advance. The dated shells also establish a minimum icesheet advance of $5 \mathrm{~km}$ during YD. This is less than the $>30 \mathrm{~km}$ large readvance reported from northern (Vorren \& Plassen, 2002; Bergstrøm et al., 2005) and western (Mangerud et al., 2016) Norway, and the c. $10 \mathrm{~km}$ readvance in southern Norway (Bergstrøm, 1999). Based on this, a larger readvance may also have taken place in southern Nordland. Studies from both Trøndelag (Reite, 1994: $>35 \mathrm{~km}$ ) and southern Nordland (Andersen et al., 1982) point to overriding of fine-grained sediments as evidence of a large readvance, but there are no existing dates that establish this assumption. Our data thus constitute the first dated regional evidence of an advancing YD ice sheet during the Tjøtta-Tautra event.

\section{Conclusions}

- We have mapped a near continuous zone of large icemarginal features in southern Nordland, Norway, and thus linked the established Tjøtta and Tautra Younger Dryas glacial events.

- The data show that rapidly flowing ice-streams operated in Velfjorden and Ursfjorden during the Younger Dryas stadial, as highly elongated glacial drift features such as MSGLs are seen to feed into large depocentres - e.g., a previously undescribed sedimentary wedge - in the fjord-terminating part of the former ice sheet.

- Radiocarbon dates of shell-bearing stratigraphical units show that Ursfjorden became ice-free in the Allerød Interstadial, before an ice-sheet readvance during the Younger Dryas chronozone buried the sediments. Whole shells found close to the YD Main Shoreline have been dated to $12-12.9 \mathrm{cal} \mathrm{ka}$ BP, which suggest that the ice-marginal features mapped in this study were deposited during early to mid-Younger Dryas. The calibrated radiocarbon dates located inland of this ice-marginal zone suggest a late Younger Dryas to early Holocene deglaciation age.

- Our data establish that a $>5 \mathrm{~km}$ large YD ice sheet readvance occurred in southern Nordland during the Tjøtta-Tautra event, but the full extent of this advance remains unknown.

Acknowledgements. This work was funded by Quaternary geology mapping programmes at the Geological Survey of Norway. Kartverket kindly granted access to bathymetric data from Ursfjorden. R. Myhren and J. A. Dahl assisted in collecting the bathymetric data in Velfjorden, whereas S. Elvenes and R. Bøe aided in gridding the bathymetric data. Reviewers Anders Schomacker and Anna Hughes provided helpful and constructive comments that greatly improved the paper. We extend our sincere thanks to all these persons and institutions.

\section{References}

Anandakrishnan, S., Catania, G.A., Alley, R.B. \& Horgan, H.J. 2007: Discovery of till deposition at the grounding line of Whillans Ice Stream. Science 315, 1835-1838. https://doi.org/10.1126/science.1138393.

Andersen, B.G. 1968: Glacial Geology of Western Troms, North Norway. Norges geologiske undersøkelse 256, 160 pp.

Andersen, B.G., Bøen, F., Nydal, R., Rasmussen, A. \& Vallevik, P.N. 1981: Radiocarbon dates of marginal moraines in Nordland, North Norway. Geografiska Annaler Series A Physical Geography, 155-160. https://doi.org/10.1080/04353676.1981.11880029.

Andersen, B.G., Bøen, F., Rasmussen, A., Rokoengen, K. \& Vallevik, P.N. 1982: The Tjøtta glacial event in southern Nordland, North Norway. Norwegian Journal of Geology 62, 39-49. 
Andersen, B.G., Mangerud, J., Sørensen, R., Reite, A., Sveian, H., Thoresen, M.K. \& Bergstrøm, B. 1995: Younger Dryas ice-marginal deposits in Norway. Quaternary International 28, 147-169. https://doi.org/10.1016/1040-6182(95)00037-J.

Bargel, T.H. 2003: Quaternary geological mapping of Central Fennoscandia and Nordland: Deglaciation, deposition, stratigraphy and applications. Doctor of Engineering thesis, Department of Geology and Mineral Resources Engineering, NTNU, 324 pp., 9 enclosures.

Bargel, T.H., Bergstrøm, B., Hilmo, B.O., Olsen, L., Storrø, G. \& Sveian, H. 1994: Guide til Midtnordenekskursjonen 1994. Kvartærgeologi og miljøgeologi i Midt Norge. Norges geologiske undersøkelse Report 94.071, 60 pp. (in Norwegian).

Batchelor, C.L. \& Dowdeswell, J.A. 2015: Ice-sheet grounding-zone wedges (GZWs) on high-latitude continental margins. Marine Geology 363, 65-92. https://doi.org/10.1016/j.margeo.2015.02.001.

Bergstrøm, B. 1999: Glacial geology, deglaciation chronology and sea-level changes in the southern Telemark and Vestfold counties, southeastern Norway. Norges geologiske undersøkelse 435, 23-42.

Bergstrøm, B., Olsen, L. \& Sveian, H. 2005: The Tromsø-Lyngen glacier readvance (early Younger Dryas) at Hinnøya-Ofotfjorden, northern Norway: a reassessment. Norges geologiske undersøkelse Bulletin 445, 73-88.

Bondevik, S. \& Mangerud, J. 2002: A calendar age estimate of a very late Younger Dryas ice sheet maximum in western Norway. Quaternary Science Reviews 21, 1661-1676. https://doi.org/10.1016/S0277-3791(01)00123-8.

Bondevik, S., Mangerud, J., Birks, H.H., Gulliksen, S. \& Reimer, P. 2006: Changes in North Atlantic radiocarbon reservoir ages during the Allerød and Younger Dryas. Science 312, 1514-1517. https://doi.org/10.1126/science.1123300.

Bronk Ramsey, C. 2009: Bayesian analysis of radiocarbon dates. Radiocarbon 51, 337-360. https://doi.org/10.1017/S0033822200033865.

Dahlgren, K.T., Vorren, T.O. \& Laberg, J.S. 2002: Late Quaternary glacial development of the mid-Norwegian margin-65 to $68 \mathrm{~N}$. Marine and Petroleum Geology 19, 1089-1113. https://doi.org/10.1016/S0264-8172(03)00004-7.

Dowdeswell, J.A. \& Fugelli, E.M.G. 2012: The seismic architecture and geometry of grounding-zone wedges formed at the marine margins of past ice sheets. Geological Society of America Bulletin 124, 17501761. https://doi.org/10.1130/B30628.1.

Eyles, N. 2012: Rock drumlins and megaflutes of the Niagara Escarpment, Ontario, Canada: a hard bed landform assemblage cut by the Saginaw-Huron Ice Stream. Quaternary Science Reviews 55, 34-49. https://doi.org/10.1016/j.quascirev.2012.09.001.

Gump, D.J., Briner, J.P., Mangerud, J. \& Svendsen, J.I. 2017: Deglaciation of Boknafjorden, south囚western Norway. Journal of Quaternary Science 32, 80-90. https://doi.org/10.1002/jqs.2925.

Hansen, L., Bøe, R., Sveian, H. \& Husum, K. 2018: Stratigraphical signatures of glacier activity, marine processes and a possible tsunami in the Leirfjorden fjord-valley system, north Norway. Boreas 47, 792-812. https://doi.org/10.1111/bor.12311.

Holtedahl, H. 1998: The Norwegian strandflat-a geomorphological puzzle. Norsk Geologisk Tidsskrift 78, 47-66.

Hughes, A.L.C., Gyllencreutz, R., Lohne, Ø.S., Mangerud, J. \& Svendsen, J.I. 2016: The last Eurasian ice sheets-a chronological database and time-slice reconstruction, DATED-1. Boreas 45, 1-45. https://doi.org/10.1111/bor.12142.

Høgaas, F. \& Sveian, H. 2015: The Younger Dryas Main Line on Leka, Norway, as determined from a high resolution digital elevation model derived from airborne LiDAR data. Geomorphology 231, 63-71. https://doi.org/10.1016/j.geomorph.2014.12.002.

Høgaas, F., Gislefoss, L. \& Olsen, L. 2018a: BRØNNØYSUND 1725-1, kvartærgeologisk kart, scale 1:50,000, Norges geologiske undersøkelse.
Høgaas, F., Olsen, L., Sveian, H. \& Sørensen, E. 2018b: VEGA 17262, kvartærgeologisk kart, scale 1:50,000, Norges geologiske undersøkelse.

King, E.C., Hindmarsh, R.C. \& Stokes, C. 2009: Formation of megascale glacial lineations observed beneath a West Antarctic ice stream. Nature Geoscience 2, 585-588. https://doi.org/10.1038/ngeo581.

Koren, J.H., Svendsen, J.I., Mangerud, J. \& Furnes, H. 2008: The Dimna Ash - a $12.8{ }^{14} \mathrm{C}$ ka-old volcanic ash in Western Norway. Quaternary Science Reviews 27, 85-94. https://doi.org/10.1016/j.quascirev.2007.04.021.

Krabbendam, M., Eyles, N., Putkinen, N., Bradwell, T. \& ArbelaezMoreno, L. 2016: Streamlined hard beds formed by palaeo-ice streams: A review. Sedimentary Geology 338, 24-50. https://doi.org/10.1016/j.sedgeo.2015.12.007.

Laberg, J.S., Eilertsen, R.S. \& Vorren, T. 2009: The paleo-ice stream in Vestfjorden, north Norway, over the last $35 \mathrm{ky}$ : Glacial erosion and sediment yield. Geological Society of America Bulletin 121, 434-447. https://doi.org/10.1130/B26277.1.

Laberg, J.S., Eilertsen, R.S. \& Salomonsen, G.R. 2017: Deglacial dynamics of the Vestfjorden-Trænadjupet palaeo-ice stream, northern Norway. Boreas 47, 225-237. https://doi.org/10.1111/bor.12261.

Lohne, Ø., Mangerud, J. \& Svendsen, J.I. 2012: Timing of the Younger Dryas glacial maximum in western Norway. Journal of Quaternary Science 27, 81-88. https://doi.org/10.1002/jqs.1516.

Lohne, Ø., Mangerud, J. \& Birks, H.H. 2013: Precise ${ }^{14} \mathrm{C}$ ages of the Vedde and Saksunarvatn ashes and the Younger Dryas boundaries from western Norway and their comparison with the Greenland Ice Core (GICC05) chronology. Journal of Quaternary Science 28, 490-500. https://doi.org/10.1002/jqs.2640.

Lyså, A. \& Vorren, T.O. 1997: Seismic facies and architecture of icecontact submarine fans in high-relief fjords, Troms, Northern Norway. Boreas 26, 309-328. https://doi.org/10.1111/j.1502-3885.1997.tb00858.x.

Lyså, A., Sejrup, H.P. \& Aarseth, I. 2004: The late glacial-Holocene seismic stratigraphy and sedimentary environment in Ranafjorden, northern Norway. Marine Geology 211, 45-78. https://doi.org/10.1016/j.margeo.2004.06.010.

Mangerud, J., Lie, S.E., Furnes, H., Kristiansen, I.L. \& Lømo, L. 1984: A Younger Dryas Ash Bed in Western Norway, and its Possible Correlations with Tephra in Cores from the Norwegian Sea and the North Atlantic. Quaternary Research 21, 85-104. https://doi.org/10.1016/0033-5894(84)90092-9.

Mangerud, J., Bondevik, S., Gulliksen, S., Hufthammer, A.K. \& Høisæter, T. 2006: Marine ${ }^{14 \mathrm{C}}$ reservoir ages for 19th century whales and molluscs from the North Atlantic. Quaternary Science Reviews 25, 3228-3245. https://doi.org/10.1016/j.quascirev.2006.03.010.

Mangerud, J., Gyllencreutz, R., Lohne, Ø. \& Svendsen, J.I. 2011: Glacial History of Norway (chapter 22). In Ehlers, J., Gibbard, P.L. \& Hughes, P.D. (eds.): Quaternary glaciations - extent and chronology. A closer look, Developments in Quaternary Science 15, Elsevier, Amsterdam, pp. 279-298. https://doi.org/10.1016/B978-0-444-53447-7.00022-2.

Mangerud, J., Aarseth, I., Hughes, A.L.C., Lohne, Ø.S., Skår, K., Sønstegaard, E. \& Svendsen, J.I. 2016: A major re-growth of the Scandinavian Ice Sheet in western Norway during Allerød-Younger Dryas. Quaternary Science Reviews 132, 175-205. https://doi.org/10.1016/j.quascirev.2015.11.013.

Mangerud, J., Briner, J.P., Goslar, T. \& Svendsen, J.I. 2017: The Bøllingage Blomvåg Beds, western Norway: implications for the Older Dryas glacial re-advance and the age of the deglaciation. Boreas 46, 162-184. https://doi.org/10.1111/bor.12208.

Marthinussen, M. 1962: C14-datings referring to shore lines, transgressions, and glacial substages in Northern Norway. Norges geologiske undersøkelse 215, 37-67.

Mathisen, T.Q. 1987: Sømna, gård og slekt I. Sømna bygdebok. Sømna kommune, Vik i Helgeland, 509 pp. (in Norwegian). 
McMullen, K., Domack, E., Leventer, A., Olson, C., Dunbar, R. \& Brachfeld, S. 2006: Glacial morphology and sediment formation in the Mertz Trough, East Antarctica. Palaeogeography, Palaeoclimatology, Palaeoecology 231, 169-180. https://doi.org/10.1016/j.palaeo.2005.08.004.

Olesen, O., Kierulf, H.P., Brönner, M., Dalsegg, E., Fredin, O. \& Solbakk, T. 2013: Deep weathering, neotectonics and strandflat formation in Nordland, northern Norway. Norwegian Journal of Geology 93, 189-213.

Olsen, L., Høgaas, F. \& Sveian, H. 2015: Age of the Younger Dryas ice-marginal substages in Mid-Norway - Tautra and Hoklingen, based on a compilation of ${ }^{14} \mathrm{C}$-dates. Norges geologiske undersøkelse Bulletin 454, 1-13.

Ottesen, D. \& Dowdeswell, J. 2006: Assemblages of submarine landforms produced by tidewater glaciers in Svalbard. Journal of Geophysical Research 111. https://doi.org/10.1029/2005JF000330.

Ottesen, D., Dowdeswell, J.A. \& Rise, L. 2005a: Submarine landforms and the reconstruction of fast-flowing ice streams within a large Quaternary ice sheet: The 2500-km-long Norwegian-Svalbard margin $\left(57^{\circ}-80^{\circ} \mathrm{N}\right)$. Geological Society of America Bulletin 117, 1033-1050. https://doi.org/10.1130/B25577.1.

Ottesen, D., Rise, L., Knies, J., Olsen, L. \& Henriksen, S. 2005b: The Vestfjorden-Trænadjupet palaeo-ice stream drainage system, midNorwegian continental shelf. Marine Geology 218, 175-189. https://doi.org/10.1016/j.margeo.2005.03.001.

Ottesen, D., Dowdeswell, J., Benn, D., Kristensen, L., Christiansen, H., Christensen, O., Hansen, L., Lebesbye, E., Forwick, M. \& Vorren, T. 2008a: Submarine landforms characteristic of glacier surges in two Spitsbergen fjords. Quaternary Science Reviews 27, 1583-1599. https://doi.org/10.1016/j.quascirev.2008.05.007.

Ottesen, D., Stokes, C.R., Rise, L. \& Olsen, L. 2008b: Ice-sheet dynamics and ice streaming along the coastal parts of northern Norway. Quaternary Science Reviews 27, 922-940. https://doi.org/10.1016/j.quascirev.2008.01.014.

Rasmussen, A. 1981: The deglaciation of the coastal area NW of Svartisen, northern Norway. Norges geologiske undersøkelse Bulletin 369, 1-31.

Reimer, P.J., Bard, E., Bayliss, A., Beck, J.W., Blackwell, P.G., Bronk Ramsey, C., Buck, C.E., Cheng, H., Edwards, R.L., Friedrich, M., Grootes, P.M., Guilderson, T.P., Haflidason, H., Hajdas, I., Hatté, C., Heaton, T.J., Hoffmann, D.L., Hogg, A.G., Hughen, K.A., Kaiser, K.F., Kromer, B., Manning, S.W., Niu, M., Reimer, R.W., Richards, D.A., Scott, E.M., Southon, J.R., Staff, R.A., Turney, C.S.M. \& van der Plicht, J. 2013: IntCal13 and Marine13 Radiocarbon Age Calibration Curves 0-50,000 Years cal BP. Radiocarbon 55, 18691887.https://doi.org/10.2458/azu_js_rc.55.16947.

Reite, A.J. 1994: Weichselian and Holocene geology of Sør-Trøndelag and adjacent parts of Nord-Trøndelag county, Central Norway. Norges geologiske undersøkelse Bulletin 426, 1-30.

Reite, A.J., Selnes, H. \& Sveian, H. 1982: A proposed deglaciation chronology for the Trondheimsfjord area, central Norway. Norges geologiske undersøkelse 373, 75-84.

Reusch, H. 1894: Strandfladen, et nyt træk i Norges geografi. Norges geologiske undersøkelse 14, 1-12.

Romundset, A., Akçar, N., Fredin, O., Tikhomirov, D., Reber, R., Vockenhuber, C., Christl, M. \& Schlüchter, C. 2017: Lateglacial retreat chronology of the Scandinavian Ice Sheet in Finnmark, northern Norway, reconstructed from surface exposure dating of major end moraines. Quaternary Science Reviews 177, 130-144. https://doi.org/10.1016/j.quascirev.2017.10.025.

Selnes, H. 1982: Paleoøkologiske undersøkelser omkring israndavsetninger på Fosenhalvøya, Midt-Norge. Cand. Scient. thesis, NTNU, 158 pp. (in Norwegian).

Stokes, C.R. \& Clark, C.D. 1999: Geomorphological criteria for identifying Pleistocene ice streams. Annals of Glaciology 28, 67-74. https://doi.org/10.3189/172756499781821625.
Stokes, C.R., Tarasov, L., Blomdin, R., Cronin, T.M., Fisher, T.G., Gyllencreutz, R., Hättestrand, C., Heyman, J., Hindmarsh, R.C. \& Hughes, A.L. 2015: On the reconstruction of palaeo-ice sheets: recent advances and future challenges. Quaternary Science Reviews 125, 15-49. https://doi.org/10.1016/j.quascirev.2015.07.016.

Svensson, H. 1959: Glaciation och Morfologi. En glacialgeografisk studie $i$ ett tvärrsnitt genom Skanderna mellan södra Helgelandskusten och Kultsjødalen. Meddelanden från Lunds Universitets Geografiska Institution. Avhandlingar XXXVI, 283 pp.

Sættem, J., Rise, L., Rokoengen, K. \& By, T. 1996: Soil investigations, offshore mid Norway: A case study of glacial influence on geotechnical properties. Global and Planetary Change 12, 271-285. https://doi.org/10.1016/0921-8181(95)00024-0.

Vorren, T.O. \& Plassen, L. 2002: Deglaciation and palaeoclimate of the Andfjord-Vågsfjord area, North Norway. Boreas 31, 97-125. https://doi.org/10.1080/030094802320129926. 